\title{
Scandinavian Belief in Fate
}

\author{
A COMPARISON BETWEEN PRE-CHRISTIAN AND \\ POST-CHRISTIAN TIMES
}

\author{
By ÅE V. STRÖM
}

In point of principle, Christianity does not give room for any belief in fate. ${ }^{1}$ Astrology, horoscopes, divination, etc., are strictly rejected.2 The early Christians found in the Scriptures prohibitions against soothsayers (Lev. 19, 31). They read there ironic statements like this: "Let now the astrologers, the stargazers, the monthly prognosticators, stand up, and save thee from these things that shall come upon thee. Behold, they shall be as stubble; the fire shall burn them" (Is. $47, \mathrm{r}_{3}$ f.), and they added themselves words like these: "We know that all things work together for good to them that love God" (Rom. 8, 28) or "It is God which worketh in you both to will and to do of his good pleasure" (Phil. 2,I3). ${ }^{3}$

Christianity entered a world, where people behaved like the Roman lady of about 100 A.D.:

1 "It is wrong to introduce features of fate into the Christian image of God" (G. Borgenstierna, Människan och ödet, Stockholm I949, p. I3). Or: "It is obvious that fate in any form cannot be accepted from a Christian point of view, whatever it may be called. The free God and free man cannot stand any interference from a third party, least of all from any power of fate" (p. roo).

2 See Otto Riedinger, Die Heilige Schrift im Kampf der griechischen Kirche gegen die Astrologie, Innsbruck 1956, and H. C. Freiesleben, Trïgen die Sterne? Werden und Wesen der Astrologie, Stuttgart I963, pp. 53-6r.

$3 \mathrm{Hj}$. Sundén tries to coordinate belief in God and in fate: "Both of them seem to imply that the whole somehow controls the life of all the parts" (Gud-ödet-slumpen, Stockholm 1947, p. 221). He seems to reach this result by interpreting the parables of Jesus as describing "a fixed order, the inexorable consequences of unmerciful, irresponsible, and unforgiving behaviour" already in this life (p. 228). Cf. the same author, "Om ödestro och gudstro", Sjuttiotredje psalmen, Stockholm I956, pp. I29142. 
If she wants to

walk to the nearest milestone she asks the stargazer's booklet for a suitable time, and when her eyelids are itching casts at once horoscope and chooses her unguent thereafter. ${ }^{1}$

But the Christian emperor Constantius II forbade astrology about $35^{\circ}$ A.D., ${ }^{2}$ and in Dante we find those who had tried to reveal fate placed in Hell with their faces on their backs. The prophet says:

Come ' 1 viso mi scese in lor più basso,

mirabilmente apparve esser travolto

ciascun tra ' 1 mento e 'l principio del casso;

ché da le reni era tornato il volto,

ed in dietro venir li convenia,

perchè ' 1 veder dinanzi era lor tolto. ${ }^{3}$

In this procession backwards are marching prognosticators from Teiresias:

perchè volle veder troppo davante,

di retro guarda e fa retroso calle, ${ }^{4}$

to Michael Scotus (d. I250), the physician, astrologer, and wizard of emperor Friedrich II of Hohenstaufen." Martin Luther called astrology a "subtle jugglery" and said about it: "Astrologia non est ars, quia nulla habet principia et demonstrationes, sed omnia ex eventu et casibus iudicat." ${ }_{6}$ His explanation of the First commandment: "Wir sollen Gott über alle Dinge fürchten, lieben und vertrauen", excludes the existence of any power of fate. ${ }^{7}$

Astrology and belief in fate, however, forced their way into Christendom, especially through the Arabs, who had translated the works of Ptolemy

1 Juvenal, Satire VI, 576-79.

2 See Jacob Burckhardt, Die Zeit Konstantins des Grossen, Neuauflage, Bern I 950, p. 158 .

3 Inferno, Canto XX, Io-15 (Dante Alighieri, Tutte le opere, a cura di F. Chi-

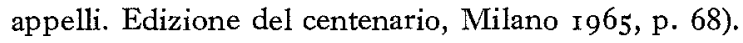

4 Stanzas $3^{8}$ f. (p. 69).

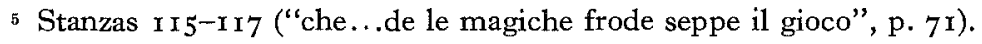

${ }^{6}$ Luthers Werke, WA, Tischreden III, Weimar r9I4, Nr. 2834 b.

7 Concerning the problem of religion and belief in fate see esp. Joachim Konrad, Schicksal und Gott, Gütersloh I947, esp. pp. 195-204. Note the remark: Fate "erhebt von sich aus keinerlei Ansprüche, kultisch verehrt und angebetet zu werden, in ihrer Weisheit gepriesen, in ihrer Nützlichkeit gelobt" (p. 197). 
(85-160 A.D.), ${ }^{1}$ the leading Greek astronomer and astrologer, interpreted and used, e.g., by the above-mentioned Michael Scotus. ${ }^{2}$ The North-Italian prince Ezzelino da Romano (d. I259) used several astrologers, amongst them the Sarazene Paul of Bagdad. ${ }^{3}$ After that belief in fate never disappeared in Christian countries, nor did it in Scandinavia in Christian times. Especially in folklore we can find it at any period: "People believed in an implacable fate. All folklore is filled up with this belief in destiny. What is to happen will happen. Nobody can escape his fate. The future lies in the hands of fate, and the time to come takes its form according to inscrutable laws." 4

The pre-Christian period in Scandinavia, dominated by pagan Norse religion, and the secularized epoch of the 2oth century, however, show more distinctive and more widespread beliefs in fate than does the Christian period. The present paper will make a comparison between these forms of belief.

\section{PRE-CHRISTIAN BELIEF IN FATE}

\section{A. Modern research}

Recent study of the old Teutonic belief in fate does not start until I 920 and then, peculiarly enough, in the realm of Anglo-Saxon research. As a matter of fact the Swede Viktor Rydberg and the Dane Vilhelm Grønbech had discussed several points connected with the topic earlier, ${ }^{5}$ but Rydberg's investigations were partly silenced, partly ignored, ${ }^{6}$ and Grøn-

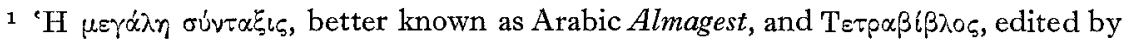
Franz Boll and E. Boer, 1940. See about this Freiesleben, op. cit. pp. 46-50.

2 Wilhelm Gundel, Sternglaube, Sternreligion und Sternorakel, Aus der Geschichte der Astrologie, Heidelberg I959, p. 5I, and Paul Bauer, Horoskop und Talisman. Die Mächte des heutigen Aberglaubens, Stuttgart 1963, p. 209.

3 For the astrology and belief in fate in the Renaissance see Jacob Burckhardt, Die Kultur der Renaissance in Italien, Atlas-Verlag, Köln, no date, pp. 367-77, and Freiesleben, op. cit. pp. 7 I -86.

4 C. H. Tillhagen, Folklig spådomskonst Stockholm I96I, p. 30.

5 V. Rydberg, Undersökningar $i$ Germanisk mythologi, I-2, r886, I889, passim (see topical index), V. Gronbech, Vor Folkeæt $i$ Oldtiden, 1-4, 1909-12.

${ }^{6}$ For this, see $\AA$. V. Ström, "Das indogermanische Erbe in der Völuspá", Numen I 966 (in the press).

5-654218 Ringgren 
bech's books were not translated into English and German until the thirties. ${ }^{1}$ The modern literature concerning the subject in question was in fact inaugurated by a Breslau dissertation by Alfred Wolf on the words for fate in Anglo-Saxon poetry, and the treatise by Richard Jente on mythological expressions in Old English. ${ }^{2}$ There attention is already drawn to three important groups of words: wyrd, zesceap-zesceaft, and orleg, which appear in the Old Icelandic urd, skgp, and orleg, all of them with the meaning of fate. $^{3}$

In I926 Fr. Kauffmann carried out a corresponding investigation in the East Teutonic area, which tried to show, that the expressions giscapu, giscafti, and urlag were taken from the language of law, the first two meaning 'judicial decision', the third 'primal law' (Urgesetz). ${ }^{4}$

During the 1930's there appeared-with or without connection with the special belief in fate of the Hitler period ${ }^{5}$ - on the average one work a year on this subject, all of them, except two, in German: M. von Kienle in I933, A. G. von Hamel (in English), W. Baetke, and H. Naumann in 1934, M. Ninck in 1935, G. Gunnarsson in 1936, H. Schneider, H. de Boor, and E. Therman (in Swedish) in $193^{8}$, and W. Gehl in $1939 .{ }^{6}$

1 V. Gronbech, The culture of the Teutons, I-3, Copenhagen 1931, Kultur und Religion der Germanen, I-II, Hamburg 1937-39. V. Rydberg, Teutonic mythology, London I 889 , does not seem to have become well known.

a A. Wolf, Die Bezeichnungen für Schicksal in der angelsächsischen Dichtersprache, Breslau I9I9, R. Jente, Die mythologischen Ausdrïcke im altenglischen Wortschatz ( = Anglistische Forschungen, 56), Heidelberg I92 I. Cf. already W. Jaehde, Religion, Schicksalsglaube... und Rätsel in den englisch-schottischen Volksbaladen, Halle 1905 , and Alois Brandl, "Zur Vorgeschichte der Weird Sisters im 'Macbeth'," Texte und Forschungen zur englischen Kulturgeschichte, Festgabe fïr F. Liebermann, Halle I 92I, pp. $252-270$.

${ }^{3}$ See especially Wolf, op. cit. pp. 48, 59 f., 88, I27, and Brandl, op. cit. pp. 25255 .

4 F. Kauffmann, "Über den Schicksalsglauben der Germanen", Zeitschrift für deutsche Philologie 50, 1926, pp. 36I-408. Objection by W. Gehl, Der germanische Schicksalsglaube, Berlin 1939, who instead proposes the translation 'highest decision' (Höchste Bestimmung), p. $2 \mathrm{x}$.

${ }^{5}$ For this question see Hj. Sundén, Gud, ödet, slumpen, pp. 36-44, and P. Bauer, Horoskop und Talisman, Stuttgart 1963, pp. 241-243.

"M. von Kienle, "Der Schicksalsbegriff im Altdeutschen", Wörter und Sachen 15, I933, p. 8I ff., A. G. van Hamel, The conception of fate in early Teutonic and Celtic religion ( = Saga book of the Viking Society 9), I934, H. Naumann, Germanischer Schicksalsglaube, Jena I934, G. Gunnarsson, Nordischer Schicksalsgedanke, München 1936, H. Schneider, "Glauben", and H. de Boor, "Dichtung”, both in Germanische 
After that time there is, as far as I know, a complete silence until $1955^{1}$, when there were two treatises in German by Mittner and Neumann. ${ }^{2}$ Finally, we have to note a paper by Strömbäck in $1959 \cdot{ }^{3}$ Let us examine some of the contents of this literature about the pre-Christian Norse belief in fate.

Walter Baetke deals especially with the following two problems: fateethics and belief in fate-faith in gods. ${ }^{4} \mathrm{He}$ emphasizes the fact, that there is an inner connection between fate and the moral behaviour of the hero, which gives the poetry its tragic standard. ${ }^{5}$ The hero has to act entirely in accordance with the decision of his fate, he has to stand in conformity with the determined model, and "that is why just the factor we are thinking of in moral decision is missing, namely the choice". ${ }^{6}$ On the contrary: it is fate that is to blame! Expressions like that of the Lay of the Hun-battle 29, "the Norn created bad luck" (illr er dómr nórna), or the famous passage in the Lay of Hildebrand, "misfortune is happening" (wêwurt skihit) show that "fate is not accepted in a fatalistic way, but accused!" 8

Further, Baetke opposes the traditional interpretation, that fate is superior to the gods. They are regin, 'the ruling ones', ${ }^{9}$ hopt, 'fetters', or Altertumskunde, ed. by H. Schneider, München 1938 (new ed. 195I, pp. 222-305, 306-430), E. Therman, Eddan och dess ödestragik, Stockholm 1938. For Baetke, Ninck, and Gehl see p. 67 n. 4, p. 68 n. 4 and p. 69 n. I.

1 An exception is the small paper by B. J. Timmer, "Wyrd in Anglo-Saxon prose and poetry", Neophilologus 26, 1944, pp. 24-33 and 21 3-228.

2 L. Mittner, Wurd (Bibliotheca Germanica 6), Bern I955, Ed. Neumann, Das Schicksal in der Edda, I (Beiträge zur deutschen Philologie 7), Giessen 1955.

${ }^{3}$ D. Strömbäck, "Till Ynglingatal to och nordisk ödestro", Septentrionalia et Orientalia studia Bernhardo Karlgren ... dedicata, Kungl. Vitterhets Historie och Antikvitets Akademiens Handlingar, 91, Stockholm 1959, pp. 386-92.

${ }^{4}$ W. Baetke, Art und Glaube der Germanen, Hamburg I934.

5 Op. cit. p. 67.

6 Baetke, op. cit. p. 68.

? Cf. Hamdismál 28 and 30.

8 Baetke, op. cit. pp. $68 \mathrm{f}$.

- This word already appears on a stone from the 8th century at Noleby: rūnō făhi raginaku[n]dō, 'I painted god-inspired runes' (Sveriges Runinskrifter, Bd. 5, "Västergötlands runinskrifter", Hft 3, Uppsala 1958, pp. 92-100: Nr. 63, Fyrunga sn, Noleby). Cf. Háv. 80:

er pú at rúnum spyrr

hinum reginkunnum

and comments on this by Wolfgang Krause, Runeninschriften im älteren Futhark, Halle 1937 , p. 5 I9. 
bond, 'bonds'. To this group Baetke also counts "das sehr merkwürdige mjotudr", a masculine word used only in the neuter sense of 'fate'.1 The result is that, according to Norse opinion, "fatalism and theism coincide"'2. If one of them is later in origin, it is belief in fate, which represents "paganism deprived of its real religious content and grown bloodless and cold". Óxinn as a god of fate is in any case a late poetical conception. ${ }^{3}$

Similar problems are discussed in greater detail by Martin Ninck in his large book on Óxinn and belief in fate. ${ }^{4}$ In his interpretation of the notion orlgg (cf. Swedish örlig, 'war'), adapted for the Hitler period, he declares, that "Krieg... ist urlag und damit zugleich 'Urgesetz' und 'Schicksal"'.

Ninck's book deals more with Óðinn than with fate. The latter, he maintains, is always experienced as suffering, and he speaks of "den pathischen Zug im heldischen Erleben". ${ }^{6}$ Ó ðinn, too, has this 'pathic' trait. "Ganz im Sinne germanischer Heldenethik, die die Ehre nur sucht, indem sie dem Spruche der Nornen gläubig sich beugt, lag die Verpflichtung auf ihm, den Lauf des Schicksals zu erfahren und nach ihm zu handeln."

To the same period belong the books of the Bonn scholar Hans Naumann and the Finlander Erik Therman, both with particular stress on the guilt of fate. The individual as well as the whole world are guilty, owing to Destiny's determination: “Man's fulfilling his inescapable duty towards life and towards fate produces a burden of guilt, and precisely the performance of his duty constitutes the guilt that causes his destruction." true of the universe: "Upon life lies guilt from the very beginning. Such a stern religion breeds with absolute necessity the idea of the guilt of the world and 'consequently the belief in its destruction' in the hardening conflict of powers.",

1 Baetke, op. cit. pp. $7 \circ \mathrm{f}$.

2 Op. cit. p. 7 r.

Op. cit. p. 78 .

${ }^{4}$ M. Ninck, Wodan und germanischer Schicksalsglaube, Jena I935.

5 Ninck, $o p$. cit. p. I3०.

${ }^{6}$ Ib. p. 198 with note 2. Similarly de Boor in: Schneider (ed.), Germanischer Altertumskunde, München 1938, 2. ed. I95I, p. 402. Opposition by Neuman, op. cit. p. 39 , note 63 .

7 Ninck, op. cit., p. 297.

8 'Therman, Eddan och dess ödestragik, p. 54.

${ }^{9}$ Therman, op. cit. p. $5^{6}$. 
The most comprehensive work on fate in the North is Walther Gehl, Der germanische Schicksalsglaube, Berlin 1939. In an earlier book Gehl described honour as a "Hineinwachsen ins Überpersönliche". ${ }^{1}$ Now he follows the same "impersonal" line with regard to fate, in calling it "eine ungreifbare, unpersönliche Macht, die als Mass und Ordnung hinter den Dingen der Sinnenwelt steht". 2 Though he treats "impersonal fate", "personified fate", and "personal fate" in different chapters, ${ }^{3}$ and though he maintains that "the Teutonic belief in fate was a perpetual struggle against the fatalistic and impersonal idea of fate," 4 he repeats the old opinionagainst Baetke-that the Teutonic gods are subject to fate, ${ }^{5}$ and makes the following statement: "Schicksalsglaube ist eher 'Weltanschauung' als 'Religion'- ja er steht zu Religion im engeren Sinne überall in mehr oder weniger deutlicher Spannung."' Has, then, the Norse man no free will? The problem is discussed by Gehl at some length. ${ }^{7}$ He states that the sources for the most part deal with fate as a power, over against which any resistance is meaningless, for instance: vinnat skjoldungar skøpum, 'princes cannot resist fate' (Helg. Hund. II, 29). ${ }^{8}$ The examples of free will are rare and late, ${ }^{9}$ and in these cases it may be said: "Aus dem Willensentschluss redet das Schicksal." "10

The latest monograph on the Norse problem of fate is the first part of a work by Eduard Neumann, more philosophical than strictly historical.11 He divides the notions of fate into two groups: $\mathrm{I}$. the conception of "Schick-

1 W. Gehl, Ruhm und Ehre bei den Nordgermanen, Leipzig-Berlin I937, p. I39.

2 Gehl, Schicksalsglaube, p. 39.

3 "Das unpersönliche Schicksal und der magische Schicksalsbegriff" (pp. 39-58), "Das personifizierte Schicksal" (p. 80-120), and "Das 'persönliche' Schicksal" (pp. 199-223).

4 Op. cit. p. 59.

5 Op. cit. p. 107 .

6 Op. cit. p. 8o. Cf. R. L. Derolez: Fate and gods are quite different things. "Vieles von dem, was ... als 'Schicksal' gilt, ist auf das Fehlen einer festgefügten, über der Menschenwelt thronenden Göttergemeinschaft zurückzuführen" (Götter und Mythen der Germanen, Einsiedeln I963, p. 215).

7 Chapter VII: "Das Problem der Willensfreiheit", pp. I82-198.

8 Op. cit. p. 183.

9 Op. cit. p. 185 .

10 Op. cit. p. 205.

11 Ed. Neumann, Das Schicksal in der Edda, I. "Der Schicksalsbegriff in der Edda" (Beiträge zur deutschen Philologie 7), Giessen I955. 
sals-Notwendigkeit", with the terms urj-verda, bond and hopt, and the sentence: what happens, has to happen, "Was wird, muss werden".1 Fate is what comes to pass. 2. the conception of a "Schicksals-Macht" expressed in the words skuld-skulu, skop-skapa, leggja, meta (Sigrdr. 2o), and implying that a kind of superwill wants it to be in this way. ${ }^{2}$ Fate is a ruling power. According to Neumann the first type belongs to a primitive people and corresponds to the gods called vanir, while the second type is connected with a more civilized and politically organized people and matches the cesir-gods. ${ }^{3}$ The second form is increasingly penetrating the Norse mind, thus giving fate in the Eddic poetry its "asic" stamp. 4

More recently there have been only small articles and parts of books dealing with the conception of destiny, except for one larger treatise by Ladislaus Mittner. ${ }^{5}$ Starting from the 'kennings' of Norse poetic style, in which he finds a consistent pessimism, ${ }^{6}$ the author proceeds to a philological analysis of the words for fate, esp. Wurd, from the Indoeuropean root * uert, Latin vertere, denoting a circular movement. Without mentioning the Indian samsāra he states, that the Teutonic conception of fate is pessimistic, most clearly expressed in wêwurt skihit. ${ }^{7}$

In a paper on Ynglingatal to and the Norse belief in fate, ${ }^{8}$ Dag Strömbäck gives a careful exegesis of the stanza in question, resulting in a new translation. ${ }^{9}$ He explains, that "according to Norse belief in fate each man had

1 Op. cit. p. 24.

2 "Der Utber-Wille will, dass es so sein soll' (op. cit.p. 52). On the Anglo-Saxon word metod see Brandl, op. cit. p. 254 and some reflections by Sundén, Gud ödet - slumpen, pp. $55 \mathrm{f}$., 6 I $\mathrm{f}$.

${ }^{3}$ Op. cit. pp. 54, 56 f. Cf. already Grønbech: "In the old country destiny was bound up with the luck of the clan... In the life of the viking fate asserted itself as a deity with a will of its own" (The culture of the Teutons II, I93 I, pp. 305 f.).

4 Neumann, p. 197.

5 L. Mittner, Wurd (Bibliotheca Germanica 6), Bern I 955.

6 Op. cit. p. 63.

7 Op. cit. pp. 96 , 104.

s D. Strömbäck, “Till Ynglingatal ıo och nordisk ödestro", Septentrionalia et Orientalia Studia Bernhardo Karlgren... dedicata (see note 23). Stockholm 1959, p. 386-92.

9 "I call it a miracle, / if Skjalf's deed / seemed to Agne's army / to be according to fate", i.e. "Skjalf's deed [of hanging her husband] is certainly not according to fate" (op. cit. p. 392). 
a certain space of life, a certain measured time to live. It seems as if sometimes not only the length of life but also the place of death were determined in advance."1

\section{B. Some important passages in the texts}

It is, of course, quite impossible in this paper to give a comprehensive picture of the Norse belief in destiny, or even to deal with a limited but suficient number of texts. Our task is to make a comparison between old and modern conceptions in this area of religion or superstition. A few representative passages may be singled out in order to indicate the background of the parallels to be drawn. I marshal them in four groups according to their meaning.

\section{What is to happen happens}

We find this sentence already in Beowulf: žeð ā woyrd swā hío scel.

Wyrd goes always as she must.

(Beow. 455) ${ }^{2}$

We find also both metod and wyrd:

swā unc wyrd zeteod,

metod manna zehwces. as fate us ordains,

which creates man's destiny.

(Beow. 2526 f.) $)^{3}$

These two expressions and zesceap have their correspondence in Heliand: wurdgiscapu, metod gimarcod endi maht godes.

So was his fate measured by the creator and God's power. (Heliand 127 f.) ${ }^{4}$

In scaldic literature we find the sentence used by Kormákr: "fighters do not conquer destiny" (skqpum vinnat), ${ }^{5}$ and: "Angry destinies reign with their

1 Op. cit. p. $39 \mathrm{r}$.

2 Wolf, op. cit. pp. 34-37. Cf. Beowulf 1233: wyrd=geosceaft, 'creation', 'destiny', and 3030: wyrda ne worda 'fates and events', for which see Brandl, "Zur Vorgeschichte der Weird Sisters", p. 253. Mittner, op, cit. p. 99, translates the last passage: "geweissagtes Missgeschick".

${ }^{3}$ Wolf, op. cit. p. 4.

4 Text and commentary in H. Ljungberg, Tor, Uppsala I 947, pp. 84-86.

5 St. 30. Text in Kock, Den norsk-isländska skaldediktningen, I, I946, p. 46. Gehl accepts the unnecessary conjecture of $\mathrm{F}$. Jónsson: máat instead of pviat (p. I83). 
own will" (valda skQp sinu/... reid at rádi).1 Nearly the same expression is found in the Edda: in Helg. Hund. II, 29, Grip. 53, Oddr. г6, line 8: "if fate did not destroy" (nema mjgtudr spilti), Fjglsv. 47, and especially the following:

Skopum vidr manngi,

ok skuluð pó hér komnir!
Nobody resists fate.

You should at all events come here!

\section{(Atlam. 48)}

It is explicitly said that fate dominates over chance:

Reơr auðna lifi en aigi hvar maðr er Fate rules life, and not [the position] kominn. where one is [- chance].

(Orkn. saga II $)^{4}$

Góds hofum tirar fengit

pótt skylim nú eða ígar deyjakveld lifir madr ekki

eptir kvið norna. ${ }^{5}$
We gained good honour, even if we should die now or to-morrow, a man does not live to the evening after the norns have spoken.

(Hamo. 30)

This type often occurs in the sagas, e.g. in the story of Njál:

Ch. 6: pat verdr hverr at vinna, sem atlat er.

Ch. 13: Ekki mun mega vidgera; pat mun verठa fram at koma, sem atlat er.

Ch. 128: Ef annars verðr auð̋t, pá mun pat verda fram at koma, ok mun ekki mega við gera.

Ch. 149: Allt mun pat fram ganga um aldr manna, sem atlat er. ${ }^{6}$
Everyone shall do the work that is set before him.

I am not able to prevent it; that will come about, which is set before us.

If something else be ordained by fate, it will come about, and I am not able to prevent it.

Everything must come to pass with man's life-time, which is set before us.

1 St. 40. Text in Kock, op. cit. p. 47.

2 See Neuman, op. cit. pp. 43, 46, and Gehl, op. cit. p. 183 .

3 'The word audna in 21 cases means 'fate', in I2 'luck' (Gehl, op. cit. p. 69).

${ }_{4}$ Orkneyinga saga, ed. S. Nordal (SUGNL 40), København I913-16, p. 20. A. B. Taylor translates: "not his own comings and goings" (Orkneyinga saga. A new translation, Edinburgh I938, p. I48.)

5 'The text of the manuscript (Cod. Reg.) is metrically too long, and F. Jónsson proposes to shorten it (De gamle Eddadigte, København 1932, pp. 342 and 359). The meaning will be the same.

${ }_{6}$ Brenmu-Njáls saga, ed. E. Ol. Sveinsson, Reykjavík 1954, pp. 20, 42, 327, and 427. 
2. Each man has his own fate

There is at least one passage in Beowulf:

Wyrd oft nereð unfazne eorl,

Wyrd often saves un undoomed man, (Beow. 573)

that is to say, a man who from the beginning is made to have success. $V Q$ luspá describes to us, how this personal destiny is given to men. The creator gods, Ójinn and Hoenir, found the first men, Askr and Embla, orlogslausa, 'without a destiny' (st. I7). But the three Norns (whose names, Urdr, VerJandi, and Skuld, are all connected with fate,) came, and

pær log log u,

par lif kuru

alda bornum

orleg seggja. ${ }^{2}$ they created law, they chose life[-models] and told destinies to the children of men.

$$
\text { (Vsp. 20) }
$$

The result appears in another Eddic lay:

Qll eru mein of metin.

All harm is measured.

(Sgdr. 20)

Destiny is thought of as so personal, that one person can be the fate of another:

Urðr Qðlinga

hefir pú a verit, rekr pik alda hver[r]

illrar skepnu.
The fate or princes have you always been, each wave of a bad destiny is driving you.

$$
\text { (Gudr.-kv. I, 24) }
$$

The fate, 'luck', of one person can compete with that of another, as is especially shown by a story in the Flateyjarbók. A merchant called Hrói was an ugiptumaðr, 'unlucky man', and was unsuccessful in business. The Danish king Sveinn Fork-beard entered into partnership with him, and the following conversation developed:

1 Wolf, op. cit. p. 4.

2 Cf. Snorra Edda 14, where Allfodr creates rulers at doema... ørlog manna, and ${ }_{15}$, where the Norns have the duty to koma til hvers manns er borinn er, at skapa $a l d r$ and to ráda orlogum manna. They create these destinies geysi-újafnt, 'specially for each person'. The scald Hallfrødr speaks of forhaldin skop norna, 'the time-honoured doom of the Norns' (Visur, st. Io, Kock, op. cit. p. 86). 
Hrói: Vanti ek, at pá megi meira gipta yđur ok hamingja en úgafa min.

Konungr: par skal à hatta, hvárt meira megi, konunglig gipt eða úgœfa hans.
Hrói: I expect that your good luck and fortune will be stronger than my ill-luck.

The king: There shall be ventured upon whether [my] royal luck or his ill-luck is the stronger.

(Styrbj. pattr Sviakappa, in Ólafs saga helga, ch. 62)1

\section{One had better not know his fate, except through divination}

The main passage is the following:

Ørlgg sin

viti engi fyrir:

peim er sorgalausastr sefi.
His fate ahead one ought not to know: for him sleep is most carefree.

(Háv. 56:4-6) ${ }^{2}$

Such a carefree situation, through lacking knowledge of one's destiny, is pictured in the following scene in Beowulf:

...there was a choice banquet, and the men drank wine. They knew not Weird, the Fate that was grim, as it had befallen many an earl...

...one of the beer-servants, eager and fated ( $f \bar{u} s$ ond frege), went to his bed.

(Beow. I232-35, I240 f.) ${ }^{3}$

There are, however, two ways of finding out one's coming destiny without any risk: the special Norse divination, called seidr, and the sacrifice, with the name of blót. A famous female soothsayer had used a woman, named $G u \partial r i \partial r$, as her assistant at the seið, and she thanked Guðrið warmly, adding: pin forlog eru mér nu oll gloggsa.

Now I see your future destinies quite clearly.

(Eriks saga rauða, ch. 3$)^{4}$

There seems to be no danger in this sort of looking into the future, and Gudridr is as successful as the seidr promised.

1 Flateyjarbók, ed. S. Nordal, Annað bindi, Akraness 1945, p. I 50.

${ }^{2}$ For this see Gehl, op. cit. p. I6r.

3 Translation by Ernest J. B. Kirtlan, The Story of Beowulf, London [I9I4]. On the quoted passage see Mittner, op. cit. p. I02.

1 Quoted from Dag Strömbäck, Sejd, Lund I935, pp. 5I and 54. 
The other method is the blót. ${ }^{1}$ It is told about the first settler on Iceland: penna vetr fekk Ingólfr at bloti mikhu, This winter Ingolf made a big sacok leitadi sér heilla² um forlog sin. rifice and sought augury for his fate.

\section{(Landnámabók, Sturlubók, ch. 7)}

About another settler there is the following comment:

porsteinn Rauðnefr... blótadi forsinn... Thorstein Rednib sacrificed to the hann var ok framsýnn mjok. waterfall... he was also very fore-seeing. (Landn. Sturl. ch. 355)

A special sacrificial instrument, the hlautteinn, which had some connection with the old Indoeuropean bundles barsman, barhis, strena, and zipe-

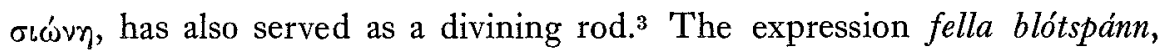
'cast divining rods', shows the method, by which the Norsemen investigated their destinies at blót-time. We find it in a least one Scaldic poem:

Flótta gekk til fréttar felli-Njordr á velli.

Draugr gat dolga Sogu

dagráð Heðins váða...

Týr vildi sá týna

teinhlautar fjor Gauta. ${ }^{4}$
The felling Niord [ $=$ the victor] went to ordeal in the field.

The spirit of Saga's enemies [ $=$ the warrior]

received augury of Hedin's peril $[=$ success in battle]...

The Tyr of the hlauttein [ = the sacrificer]

was to destroy the lives of the Gauts.

\section{Some philological remarks}

The Norse word mjQtudr, Anglo-Saxon meotod, is mostly translated 'that which is measured', 'that which is allotted'.5 Professor Dumézil, however,

1 See Ake V. Ström, "The king-god and his connection with sacrifice in old Norse religion", La regalità sacra, Suppl. to Numen IV, Leiden 1959, esp. pp. 713 -15 .

2 About the neutral heill, meaning 'omen', 'augury', see Baetke, Das Heilige im Germanischen, Tübingen 1942, p. 61.

${ }^{3}$ See Ström, op. cit. pp. 705-07, and the same author, "Die Hauptriten des wikingerzeitlichen Nordischen Opfers", Festschr. Baetke, Leipzig 1966, p. 72.

${ }^{4}$ Einars Skálaglams Vellekla, st. 30, Kock, op. cit. p. 69.

5 So F. Jónsson, Lexicum Poeticum, København 1913-16, p. 408, F. Ström, Nordisk hedendom, Göteborg 196r, p. I4r. Cf. Grønbech, The culture, p. 326: Mjotu $\partial r$ is a ritual expression for luck... bound up with the sacrifice", and Sundén, op. cit. p. 55 . 
in an article on a rather different subject, ${ }^{1}$ writes the following note apropos the Latin word modus, Oscian med-diss: "Cf. les valeurs de la racine en irlandais (midiur, 'je juge', com-midethar, 'il gouverne'); en vieux-scandinave (mjotudr, 'juge, chef'), en grec ( $\left.\mu \varepsilon ́ \delta \omega \nu, \Lambda \alpha_{0}-\mu \varepsilon \delta \omega \nu\right) .{ }^{\prime \prime 2}$ Consequently, we ought to take the male gender of mjotudr seriously and translate: 'the measurer', i.e. 'the dispenser of fate'; thus there is nothing 'merkwürdig' about the word at all. ${ }^{3}$

A similar figure is Narfi (Norfi, Norr), ${ }^{4}$ the father of Night (nótt). Rydberg derives the name from njgrva, 'to bind with narrow bonds', and translates 'he who binds narrowly'; he proceeds to show that Narfi is the same as Mimr (Mimir) in Vsp. 28 and 46, Sigrdr. $14 .{ }^{5}$ Detter has pointed out

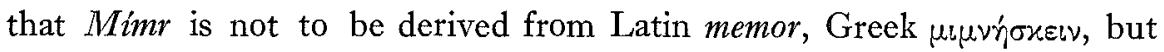
ought to be connected with Anglo-Saxon mämrian, 'to brood', Dutch mijmeren, 'to dream', and Norwegian meima, 'to measure', from the old root *mer ${ }^{6}$ Consequently, we can combine $M i m r$ with meotod-mjgtudr. The word mimameidr (Fjolsv. 20) is not 'Mímirs tree', which would suppose a third form of the name, Mimi, but 'the tree of measurement'.7

Gehl, with some hesitation, accepts Detter's identification of Mimr with mjotudr and with Mitothyn in Saxo, 8 the last name being a latinized form of the same word as mjotudr. ${ }^{9}$ If $M i m r$ is also the god of fate or a god of fate,

1 G. Dumézil, "Ordre, phantasie, changement dans les pensées archaiques de l'Inde et de Rome", Revue des études latins 32, I954 (Paris I955), p. I39-162.

2 Dumézil, op. cit. p. I5 I, note 4.

${ }^{3}$ Cf. the quotation from Baetke, above p. 68.-.The new translation in Geir T. Zoëga, A concise dictionary of Old Icelandic, Oxford r952, s.v., Åke V. Ström, in: Ringgren-Ström, Religionerna $i$ historia och nutid, 3rd ed., Stockholm 1964, p. 379, and, before Dumézil, in Ljungberg, op. cit. p. 85 .

4 Snorra Edda Gylf. 10, Vafpr. 25.

5 Rydberg, op. cit. I, pp. 459-63.

"Ferd. Detter, "Zur Ynglingasaga", Beiträge zur Geschichte der deutschen Sprache und Literatur XVIII, I894, pp. 72-105.-The Norse word meta, too, has in various Indo-European languages the meaning of 'measure' as well as of 'meditate' (de Vries, Altnordisches Etymologisches Wörterbuch, Leiden 1956, p. $3^{85}$ ).

7 Detter, op. cit. p. 75, note I.

8 Saxonis Gesta Danorum, ed. J. Olrik-H. Raeder, Hauniæ I93 I, I: 7: 2 (p. 25).

9 "Mimir könnte eine Nebenform für die vermutlich alte Schicksalsgottheit Metod sein, eine Annahme, die durch Saxos Bericht über Mitothyn wesentlich gestützt wird" (Gehl, Der germanische Schicksalsglaube p. II 3, n. 253, cf. p. 22, n. 17). For Mitothyn =mjgtudr see ib. p. ro6.-Dumézil, in connection with his conception of the Mitothyn episode in Saxo as a duplicate of the story of the fight be- 
we need not affirm the existence of two wells under the root of Yggdrasill, the well of $U r d r$ (Urdarbrunnr, Vsp. I9, Háv. III) being then the same as the well of Mimir (Mimisbrunnr, Vsp. 28). ${ }^{1}$

The combination of Mimir and mjotudr is supported by the following passages, in one of which Yggdrasill (in Vsp. 2 called mjotvidr!) is connected with mjotudr (and Mimir!), ${ }^{2}$ and in the other Mimameidr is also combined with mjgtudr:

Leika Mims synir, en mjotudr kyndis... malir Ódinn við Mims hofud; skelfr Yggdrasils askr standandi.
The sons of Mímr play, and fate is kindled...

Ódinn talks

to Mímr's head;

the ask Yggdrasill

trembles, as it stands. (Vsp. 46 f.).

Mimameiðr hann heitir, en pat manngi veit af hverjum rótum renn... sá er hann med mønnum mjotudr.
His name is Mimameiðr, and nobody knows from what root it rises... he is such a dispenser of fate for men.

(Fjolsv. 20, 22).

Leaving the Norse conception of fate we only want to add that the old Scandinavians did not make any strong distinction between theism and fatalism, nor between the personal and the impersonal in the concept of fate. ${ }^{3}$ Norse culture, being impersonalistic in its nature, lacked our clearcut notion of personality, 4 and consequently no sharp distinction, like

tween the eesir and the vanir (Le saga de Hadingus, Paris 1953, pp. Ioo-II3), offers a rather different interpretation: Mitothyn = Mithothyn (the first edition of Saxo, Paris I5I4, and the second, Basel I534, by Dumézil called "l'édition princeps", have: Mithotyn) =mjoð-Óðinn, 'the Óðinn of mead' or 'the mead of Óðinn' (ib. p. III, n. 3).

1 "Es berührt eigenartig, dass unter dem Weltbaum zwei Brunnen liegen sollen, in deren einem die Nornen wohnen, während der andere die Gabe der Wahrsagung verleiht. Man möchte annehmen, dass es sich hier ursprünglich um einen Brunnen gehandelt hat"' (Gehl, op. cit. p. II3).

2 Cf. Yggdrasill in connection with $u r \partial r$ and $ø r l o g$ in $V s p$. I9 f.

3 Cf. the oscillation between personal and impersonal in the case of $\ddot{\alpha} \tau \eta$, $\tau \dot{v} \chi \eta$, etc. See above C. M. Edsman, pp. $24 \mathrm{f}$.

${ }^{4}$ For this see Ake V. Ström, Vetekornet, Studier över individ och kollektiv, Uppsala 1944, pp. 37-45 (English summary p. 432). 
our's, was made between personal powers and impersonal fate. ${ }^{1}$ So mjgtudr is sometimes a person (Oddr.-gr. I6, Sig.sk. $7 \mathrm{r}$ ), sometimes a tree (Fjolsv. 22), a sword (Snorra Edda Skaldsk. r: 8) or an impersonal power (Vsp. 46). In a similar way the old word $u r d r$, fem. or (seldom) masc., oscillates between person (Weird sister) and power, ${ }^{2}$ but it can also be used of a real, living person: Urdr qðlinga hefir pú ae verit (above p. 73).

\section{POST-CHRISTIAN BELIEF IN FATE}

\section{A. The situation.}

In comparison with the folkloristic concept of fate in Christian times the secularized man of the 2oth century shows more and richer forms of fatalistic belief. Oswald Spengler represents in his doctrine of culture, as set forth in his work Der Untergang des Abendlandes (1919), an entirely pagan idea of destiny. ${ }^{3}$ Theophil Spoerri gives the following description of the new way of thinking in our century: "Die Vorsehung wird zum Schicksal, die klare Offenbarung zum zweideutigen Orakel, das gläubige Gebet zur magischen Beschwörung." ${ }_{4}$ Kismet, ${ }^{5}$ an international vogue-word, served in the thirties as an expression for the belief in fate. ${ }^{6}$ Trends in modern psychology have appeared to give scientific sanction to certain ideas of fate: "What we call fate is the totality of those psychological mechanisms, against which we feel ourselves powerless." In popular thought, inheri-

1 Cf. H. Schneider: 'Was ist aber 'Schicksal' anderes als der Begriff eines formlosen 'Mächtigen', das sich unseren Berechnungen und Einflüssen entzieht; sei es ein noch oder ein wieder Formloses? Im einen Fall ist das Göttliche noch nicht menschlich gefasst, im anderen hat es enttäuscht, wird deshalb aus der Menschengestalt wieder entlassen und kehrt zur alten Rätselhaftigkeit zurück" ("Glauben", Germanische Altertumskunde, p. 257).

2 See Mittner, Wurd, p. 87 f, with note 173 .

3 See Theophil Spoerri, Die Götter des Abendlandes, 3rd ed. I932, p. 132.

4 Op. cit. p. 15.

5 The Turkish form of Arabic qismah, "the share or portion, attributed by God to man" (H. Ringgren, Studies in Arabian fatalism (- Uppsala Universitets Arsskrift 1955: 2), pp. 106 and 156 . Cf. Konrad, op. cit. p. 198.

6 Spoerri, op. cit. p. 39 f.

7 Poul Bjerre, Korset och livsbägaren, Den efterlkristna människans tro och krav, Stockholm i 927, p. ıoo. For a commentary see Åke V. Ström, Vetekornet, pp. 71-76. The quoted passage, as well as the subtitle, disappeared in the and edition of Bjerre's book, Stockholm I 940 . 
tance and environment determine the destiny of man, ${ }^{1}$ and nearly all the leading psychologists have a behaviouristic background (Tolman, Hull, Skinner, Murray, Cattel, Lewin etc.; exception: Allport). ${ }^{2}$ In a recent pamphlet the present situation is described thus: "Man läßt die Arme schlaff am Leibe herunterfallen und beugt sich schweren Herzens, aber stumm wie ein Tier, unter das Joch, das dieses grauenvolle Schicksal durch Vererbung und Umwelt, durch Charakterveranlagung und Lebensmitgift einem aufgebürdet hat."'3 Astrology is as much in vogue as in the Renaissance.4

The revival of the fatalism is intimately bound up with modern superstition and its consequences. ${ }^{5}$ Our world is shrinking, distances have grown shorter, and foreign cultures have come nearer. Accordingly, purely pagan belief in stars and fate is able to infect Europe, now as during the Renaissance. The great solar eclipseon the 5 th of February 1962, caused by the conjunction of the sun, the moon and the earth, Jupiter, Saturn, Venus, Mars, and Mercury in the constellation of Capricorn, ${ }^{6}$ created alarm in nearly the whole world. The Prime minister of Burma $\mathrm{U} \mathrm{Nu}$ sacrificed personally during a whole week, Indian astrologists predicted the destruction of the world, ${ }^{7}$ and Lorcher Astrologischer Kalender in Germany announced, that "diese totale Verfinsterung ganz gewaltige Katastrophen, Umwälzungen, Kriege oder aber auch Veränderungen der Erdoberfläche verursachen wird". 8

A woman expert, Evangeline Adams, holds the opinion, that nations, too, have their horoscopes, and that the United States of America, as being born on the $4^{\text {th }}$ of July I 776 at 3: 03 a.m., has a horoscope, which shows the

I "Ingen videnskapsmann vilde vel våge å sette formelen så nakent op: arv † miljø = skjebne. Men allikevel er dette faktisk den formelen som mange mennesker tenker efter nu for tiden." (E. Berggrav, Legeme og sjel, Oslo I933, p. 68.)

${ }^{2}$ See Calvin S. Hall-Gardner Lindzey, Theories of personality, New York 1957, pp. 157-419, K. B. Madsen, Moderne psykologiske teorier, 2 ed., Copenhagen 1965, pp. I7-1 I7, esp. p. I03.

3 Hans Dannenbaum, Schicksal oder Schuld, Velbert (Rheinl.) o. J. [1964], p. 4.

4 Gundel, op. cit. pp. 148-164, Freiesleben, op. cit. pp. 89-105.

5 Paul Bauer, Horoskop und Talisman, pp. I I-22, Kurt E. Koch, Der Aberglaube, Öhringen o. J. [1965].

6 The astronomer Freiesleben has Aquarius instead of Capricorn (op. cit. p. 100).

7 Svenska Dagbladet I febr. I962.

8 Bauer, op. cit. p. 250. 
country's great cultural importance etc. ${ }^{1}$ According to Patrice Boussel

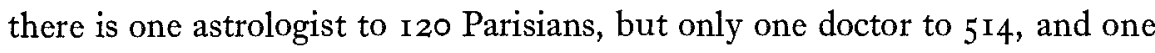
clergyman to 5000 . The French people pay ten times as much to fortunetellers as the state does to scientific research. ${ }^{2}$

How do matters stand in Sweden? In $193^{\circ}$ no Swedish magazine published horoscopes, in $194^{\circ}$ and $195^{\circ}$ four of them ${ }^{3}$ contained articles on the stars, and in 1963 there were horoscopes in 13 magazins, besides daily newspapers. ${ }^{4}$ Books on astrology and soothsaying are more and more often translated into Swedish. ${ }^{5}$

\section{B. Two Swedish investigations}

In the spring of 1963 a small investigation concerning chance, fate, and horoscopes was carried out in Stockholm. ${ }^{6}$ The material consists of $25^{\circ}$ oral interviews with people selected by chance. Unaware of this research, the present writer in the spring of 1964 made a somewhat larger investigation of the same subject in a suburb of Stockholm (Handen). A questionnaire with 16 questions was answered by $44^{\circ}$ young people, i.e. all the pupils of 14-16 years of age in Handen's public school. They wrote anonymously and did not know the author of the questions and the receiver of the answers, but only the scientific purpose of the inquiry, which was conducted during school-hours by a student of professor Husén's. Here is a translation of the questionnaire developed by myself and my wife, who also worked up the answers statistically.* The number of answers are inserted.

1 Dagens Nyheter, ed. B, 3I Dec. I964.

2 Expressen 20 Dec. I964.

3 Hemmets Veckotidning, Vårt Hem, Veckorevyn and Allas Veckotidning.

4 Berndt Gustafsson, Religionssociologi, Stockholm 1965, p. 44, Gud i storstad. Undersökningar utförda vid Religionssociologiska Institutet i Stockholm, Stockholm I963, p. I44 f. Cf. about similar investigations in Germany Freiesleben, op. cit. pp. 103-105, and in USA Svenska Dagbladet 25 April 1966.

5 E.g. Eleanor Kirk, Planeternas inflytande på människans liv, Stockholm 1926, Nostradamus profetior. Världens öden $1555-2797$... tolkade av Åke Ohlmarks, I960, and Konsten att spå $i$ kort. Sepharials klassiska handbok i översättning av Alke Ohlmarks, Stockholm i 960 .

: Gud $i$ storstad, 1963, p. 138-146.

* I here want to express my gratitude to the Provost, fil.lic. Olle Flodby, and to my wife, fil. kand, Siv Ström. 


\section{Questions concerning modern belief in fate.}

Section I: "Que sera, sera, Whatever will be, will be."

I. Do you think, that on the whole what happens is settled in advance?

$\begin{array}{llll}\text { yes } & \text { no } & \text { do not know } & \text { no answer } \\ 55 \text { (I } 2.5 \text { percent }) & 3 \text { I4 (7I percent) } & 69 \text { (I6 percent) } & 2 \text { (o.5 percent) }\end{array}$

2. How, above all, is that which happens settled?

by fate by fate and chance by chance by God no answer $\begin{array}{lllll}13 \mathrm{I}(30)^{1} & 6(\mathrm{I}) & 246(56) & 46(10.5) & \text { II (2.5) }\end{array}$

3. Which influence has inheritance and environment of a person on what happens to him? total great only little no answer $26(6) \quad 272(62) \quad 136(31) \quad 6(\mathrm{I})$

4. Is it possible for a person to influence that which is to happen to him?

$\begin{array}{llll}\text { yes } & \text { no } & \text { a bit } & \text { no answer } \\ \text { r74 (39) } & \mathrm{x} \times 2(25) & \mathrm{x}_{52}(35) & 2 \text { (I) }\end{array}$

5. Can you increase your luck by

a) living better and more up-rightly?

$\begin{array}{llll}\text { yes } & \text { no } & \text { a bit } & \text { no answer } \\ 204(46) & \mathrm{x}_{4} \mathrm{I}(32) & 88(20) & 7(2)\end{array}$

b) making special arrangements?

yes

$\begin{array}{llllll}\text { have a mascot } & \text { pray } & \text { something else } & \text { no } & \text { do not know } & \text { no answer } \\ \text { II6 (26) } & 98(22) & \text { II (2.5) } & 290(48) & 6(\mathbf{I} \cdot 5) & \text { o (0) }\end{array}$

c) avoid certain things, for example use the number $\mathrm{r}_{3}$, walking under a ladder, breaking a mirror?

$\begin{array}{llllc}\text { yes } & \text { possibly } & \text { no } & \text { do not know) } & \text { no answer } \\ 25(6) & \text { I3 (3) } & 389(88) & \text { I }(-) & \text { I2 (3) }\end{array}$

\section{Section II: "It is written in the stars,",}

6. Do you read the newspapers' horoscopes and predictions, based on the position of the stars, your birthdate etc.?

$\begin{array}{llll}\text { often } & \text { sometimes } & \text { never } & \text { no answer } \\ 146(33) & 256(58) & 37(9) & \text { I }(-)\end{array}$

7. Do you believe in a connection between such things (stars, date of birth, etc.) and the progress of a person?

$\begin{array}{llll}\text { yes } & \text { no } & \text { do not know } & \text { no answer } \\ 35(8) & 304(69) & 99(22.5) & 2(0.5)\end{array}$

8. Do you believe in other methods to find out one's destiny?

$\begin{array}{llll}\text { yes } & \text { no } & \text { possibly } & \text { no answer } \\ 48(\mathrm{II}) & 344(78) & 35(8) & \text { I3 }(3)\end{array}$

1 The figures in parentheses mean percentages.

2 The Swedish translation of the song hit "C'est écrit dans le ciel" is more 'astrological' than the French original text and runs; "Det har stjärnorna sagt". 
9. Do you know someone, who, in earnest, has had his fortune told? yourself someone whom you know nobody $8(2)$ $92(2 \mathrm{I})$ $336(76)$ no answer $4(\mathrm{I})$

Section III: "Pride will have a fall."

Io. Do you think that bragging involves bad luck?

$\begin{array}{llll}\text { yes } & \text { no } & \text { sometimes } & \text { no answer } \\ 72(16) & \text { I32 (30) } & 232(53) & 4 \text { (I) }\end{array}$

II. Do you think that bad luck more easily hits a person who talks about his luck (e.g. a person gets ill who says: I have not been ill for ro years)?

$\begin{array}{llll}\text { yes } & \text { no } & \text { sometimes } & \text { no answer } \\ 25(6) & 322(73) & 90(20) & 3(\mathrm{r})\end{array}$

I2. Have some people good luck, others bad luck?

$\begin{array}{llll}\text { yes } & \text { no } & \text { do not know } & \text { no answer } \\ 279(63.5) & 63(14) & 95(22) & 3(0.5)\end{array}$

13. What is the cause of this difference?

$\begin{array}{lllll}\begin{array}{l}\text { their } \\ \text { character }\end{array} & \begin{array}{l}\text { character and } \\ \text { chance }\end{array} & \text { chance } & \text { inborn } & \text { luck } \\ 58\left(\mathrm{r}_{3}\right) & 4(\mathrm{I}) & 234(53) & 73(\mathrm{I} 6.5) & 7 \mathrm{I}(\mathrm{I} 6.5)\end{array}$

I4. Each section above is headed by a quotation. Are they true?

\begin{tabular}{|c|c|c|c|c|c|c|c|c|}
\hline \multirow[b]{2}{*}{$\begin{array}{l}\text { all of } \\
\text { them }\end{array}$} & \multirow[b]{2}{*}{ none } & \multicolumn{5}{|c|}{ only quotation number } & \multirow{2}{*}{$\begin{array}{l}\text { do not know } \\
\text { and obscure } \\
\text { answers }\end{array}$} & \multirow[b]{2}{*}{ no answe } \\
\hline & & I & II & II & & & & \\
\hline & I $23(28)$ & $55(\mathrm{r} 2.5)$ & $9(2)$ & $38(9)$ & $2(0.5)$ & $22(5)$ & $92(2 \mathrm{I})$ & $24(5)$ \\
\hline
\end{tabular}

Accordingly voting quotation

I (Que sera...) true: I 54 (35)

II (It is written...) true 86 ( 19.5$)$

III (Pride will...) true I 35 (30.5)

The most interesting figures are probably the following:

$5^{6}$ percent believe in chance, $3^{\circ}$ percent in fate as determiner of destiny (question 2),

35 percent believe that what is to happen happens (question I4, cf. question $\mathrm{r}$ ),

26 percent believe in mascots (question $5 \mathrm{~b}$ ),

33 percent read horoscopes frequently, 58 percent sometimes, together 9I percent (question 6 ),

I6 percent or possibly 69 percent believe in the danger of hubris (question Io), 6 or 26 percent believe in nemesis (question $\mathrm{Ir}$ ),

1 Answers II + III are not represented. 
I9,5 percent hold the song hit "It is written in the stars" to be true (question 14 ).

Only II, or possibly 19, percent believe in soothsaying and auguries (question 8), but no less than 63.5 percent think, that some people are born to luck, others to bad luck (question 12).

It is interesting to compare these results with those of the Stockholm investigation of 1963 .

The figures about chance and fate are not quite comparable. In Stockholm people were asked about the origin of accidents, ${ }^{1}$ in Handen about the background of all that happens (question 2), but perhaps young people in the latter case think primarily of accidents.

Here are the figures in percent:

$\begin{array}{llccccc} & & \text { chance } & \text { fate } & \text { negligence } & \text { God } & \begin{array}{c}\text { do not } \\ \text { know }\end{array} \\ \text { Stockholm } 1963 & \text { men } & 38 & 21 & 43 & - & 14^{2} \\ & \begin{array}{l}\text { women } \\ \text { together }\end{array} & 3 \mathrm{r} & 37 & 2 \mathrm{r} & - & 25 \\ & & 25 & 28 & - & 17 \\ \text { Handen } 1964 & \text { boys } & 64 & 2 \mathrm{r} & - & & \\ & \text { girls } & 48 & 38.5 & - & & \\ & \text { together } & 56.5 & 30.5 & - & 10.5 & 2.5\end{array}$

In both cases the main result is the same: male individuals believe more in chance, females in fate. The percentage of believers in fate is only insignificantly higher in Handen than in Stockholm, but concerning chance it is nearly twice as high-certainly depending upon the lower age.

People in Stockholm were asked about the determination of the hour and the manner of death, ${ }^{3}$ which can be compared with our question I about predestination:

$\begin{array}{lllc} & \text { yes } & \text { no } & \text { do not know } \\ \text { Stockholm 1963 } & 36 & 45 & 19 \\ \text { Handen } 1964 & 12.5 & 71 & 16.5\end{array}$

1 Gud i storstad, p. I39.

2 The totals of these figures are more than roo percent, because the investigator has used the unusual method of counting two answers by one person as two! Cf. our treatment of the answers to our questions 13 and 14 above.

${ }_{3}$ Op. cit. p. 140. 
In both places the negative answers predominate, but the lower age in the Handen material gives more negative answers.

Are some people luckier than others (question I2, Handen), respectively, are born with more good luck (Stockholm¹)?

$\begin{array}{llllc} & \text { yes } & \text { no } & \text { do not know } \\ \text { Stockholm I963 } & \text { I8-29 years } & 27 & 62 & \text { I I } \\ & \text { 60 and above } & 56 & 37 & 7 \\ \text { Handen I964 } & \text { total } & 40 & 48 & \text { I2 } \\ \text { I4-I6 years } & 63.5 & 14 & 22.5\end{array}$

Here we find a great difference. More young people in the suburb believe in inborn luck than do even people of 60 or more years of age in town.

Every third person in Stockholm and every second under $3^{\circ}$ years of age confesses having a mascot.2 There are many more people who believe that mascots give better luck (question $5 \mathrm{~b}$ ) than those who believe in luck through avoidance (question $5 \mathrm{c}$ ). The comparison runs as follows:

$\begin{array}{llrrc} & \text { yes } & \text { no } & \text { do not know } \\ \text { Stockholm I963 } & \text { over 60 years } & 4 & 92 & 4 \\ & \text { 30-60 years } & 6 & 84 & \text { 10 } \\ \text { Handen I964 } & \text { I8-29 years } & \text { I2 } & 73 & 15 \\ \text { I4-I6 years } & 26 & 48 & \text { I.5 }\end{array}$

The percentages of those using horoscopes in Stockholm $^{3}$ and Handen (question 6) are as follows:

$\begin{array}{llccc} & & \text { often } & \text { sometimes } & \text { never } \\ \text { Stockholm } 1963 & \text { men } & 6 & 34 & 60 \\ \text { Handen } 1964 & \text { women } & 12 & 46 & 39 \\ & \text { boys } & 7 & 77 & 15 \\ & \text { girls } & 58 & 39 & 2\end{array}$

The females and the younger persons read much more horoscopes than males and older persons. The believers in them are grouped this way:

$\begin{array}{lccc} & \text { yes } & \text { no } & \text { do not know } \\ \text { Stockholm } 1963 & 9 & 74 & \text { 17 } \\ \text { Handen } 1964 & 8 & 69 & 23\end{array}$

\footnotetext{
1 Op. cit. p. I4I.

2 Op. cit. p. $143 \mathrm{f}$.

3 Op. cit. p. 145.
} 


\section{COMPARISON BETWEEN PRE-CHRISTIAN AND POST-CHRISTIAN BELIEF IN FATE}

To characterize the difference between the two forms of fatalism before and after Christianity, we will make use of the phenomenological pattern, drawn up by C. J. Bleeker ${ }^{1}$ and applied by Helmer Ringgren in his introductory lecture. ${ }^{2}$ According to this pattern there are five methods of grasping and interpreting what happens. I Scandinavia these apply as follows.

\section{A. Types of fatalism}

\section{The wheel of Fortuna is turning arbitrarily}

This type is not met with in pre-Christian times, because fate is bound up, measured, and ruled, as the words tell us (bond, metod, regin). Fate has a coherent plan.

On the other hand this type is predominant in modern time: belief in chance prevails over belief in fate, and inheritance and environment are considered to have great, though not exclusive, significance (question 3).

\section{Fate has something to do with birth}

This type has two subdivisions: a) Some (female) personages of fate (good or bad) stand at the cradle of the child with gifts, b) The constellation of stars in the moment of a child's birth is significant for its future life.

Type $2 \mathrm{a}$ is current in pre-Christian religion. The Norns create the destinies of each man. But time has no great importance in Norse religion, ${ }^{3}$ and there is no astrology to be found. Possibly there is a small astrological embryo in an Eddic lay, according to which in the birth-night of the child the Norns come and twist its thread of fate:

1 C. J. Bleeker, The sacred bridge, Leiden I963, pp. I $14-1$ I6.

2 Helmer Ringgren, "The problem of fatalism", above, pp. 13-I5.

3 I cannot agree with Folke Ström in connecting $u r \partial r$ with time (Nordisk hedendom, Göteborg I96I, pp. 143 f.).

4 Helg. Hund. I, 2 f.- In spite of his own opinion, that the Teutonic goddesses of fate were originally not spinners but weavers, Mittner writes: "Von derselben Wurzel [*uert, see above, p. 70] stammt auch mhd. wirtel 'Spinnwirtel'; das schien den Schluss zu berechtigen, die Wurd sei eine den Parzen ähnliche Schicksalsspinnerin gewesen" (Wurd, p. 90). 
ok und mána sal

midjan festu.

par austr ok vestr

enda fálu.
Under the hall of the moon

they fixed the middle /of it/.

In east and west

they hid the ends.

(Helg. Hund. I, 3 f.).

This cosmic scene is, as far as I know, the only trace of astrology in the Norse texts. ${ }^{1}$

Among modern youth we find at least great interest in and sensitiveness for "what is written in the stars", that is, type $2 \mathrm{~b}$. No instances of type $2 \mathrm{a}$ are found.

\section{There is an inscrutable world-order (rta in India, tao in China)}

The order in the world is reliable and causes optimism. This type is difficult to discover in the North. Surely there is a definite plan, which is carried into effect without human effort, but there is no principle like rta, İ́u. etc. and no optimism. In modern fatalism the type is completely lacking.

\section{Man is doomed to an inescapable destiny}

The knowledge of this causes a pessimistic view of life. On the whole, I think Professor Bleeker is right in finding this type in Greek tragedy and in Norse heroic literature. ${ }^{2}$ All expressions in part I:B:I of the present paper point in this direction.

However, a slight reservation may not be out of place. Man's achivement plays a certain rôle, in spite of all. We meet a sort of semipelagianism, similar to the one found in Greece. ${ }^{3}$ In the Vatnsdola saga, for instance, it is admittedly said as a general rule: 'It is not possible to 'break upon'

1 The most interesting urdar-máni, 'weird-moon', in Eyrbyggja saga ch. 52, is seen on the wall, not in the sky. - In the I4th century the first instances of astrology appear in the North through continental influences (See Anne Holtsmark, "Horoskop", Kulturhistoriskt lexikon för nordisk medeltid, VI, Malmö r96I, col. 674 f.). We find quite the contrary amongst the Celts: the Druids multa de sideribus atque eorum motu ... disputant (Cæsar, De bello Gallico VI: 14: 6).

2 Bleeker, op. cit., pp. I I $5 \mathrm{f}$.

a Edsman, above, p. $33 \mathrm{f}$. 
(fight against) fate" (brjótask við forlogunum, ch. 9). ${ }^{1}$ But in an unguarded moment it is said that Ingimundr went to Iceland "more as a result of fate than of [his own] desire" (meirr af forlggum ... en fýsi, ch. I I), ${ }^{2}$ and in ch. 29 (perhaps the best example): Gróa finds it difficult to stand against the luck of the sons of Ingimundr, but she causes a landslide to come upon them with the words: "Be it, as it was prepared [by fate]" (Fari nu hvat sem buit er). ${ }^{3}$

Modern faith, too, is an exponent of type 4. A third of the investigated youth consider the song "Que sera sera" to be true. But the determination is now placed in inheritance and environment. A mechanistic, biological view of life is behind this new fatalism.

\section{The omnipotent God determines man's destiny}

This type, of course, is not to be found in the two bodies of material before us.

\section{B. Types of man's action}

As to the question of man's attitude towards destiny, we have to discuss briefly Professor Maass' pattern ${ }^{4}$ and its application to the Norse material.

The first type, called the primitive interpretation, "sums up", according to Ringgren, "too much under one heading".5 That is really so; we must e.g. distinguish between two ways of escaping fate: by sacrifices and by man's own will. Norse men held the position, that they could alter their destinies by blót (p. 75), and they gave some room for human will and desire in the realm of shaping the fate (p. 86).-The position of modern fatalism is shown by the answers to question 4 : it is possible to influence one's destiny a good deal (p. 8r).

The heroic view is, in Ringgren's opinion, "more or less identical with Bleeker, No. 4", 6 which we have discussed at some length. It is an inter-

1 Vatnsdoelasaga, ed. Finnur Jónsson, København 1934, p. 27, 1. 9. Cf. ch. I3 (p. 33, 1. I I f.). See H. Neuberg, Der Aberglauben in den Islendinga Sögur. Thesis Jena, Riga I926, p. Io, and Åke V. Ström, Vetekornet, p. 45.

2 Vatnsdolasaga, p. 31, 1. 22 f.

3 Ib. p. $83,1.3$.

1 Above, pp. 16 f.

5 Above, p. I7.

- Above, p. I7. 
esting feature, that no stubborn Promethean attitude is expressive of the Norse mind.1 The famous Swedish poet Tegnér's pastiche in "Fritiof's Saga" has no historical or psychological authenticity:

Hur glad, hur trotsig, hur förhoppningsfull!

Han sätter spetsen av sitt goda svärd

på Nornans bröst och säger: du skall vika. ${ }^{2}$

Every trace of belief in hubris or nemesis is lacking in the Norse sources.3 In the modern material it shines dimly through (I6, resp. 6 percent). But 30,5 percent hold the opinion that pride will have a fall.

The last two types of professor Maass': destiny can be denied or fully accepted, are not found out in our material. There is no attitude like the Arabic sabr in pre- or post-Christian thought in Scandinavia.

Comparative religion finds an amazing multitude of remnants from preChristian religion, still alive in the Nothern countries. The celebration of Christmas and Easter bears the impress of pagan customs and food ${ }^{4}$, most of the weekdays are named for the Norse gods, and a trace of the goddess $V \dot{a} r$ is left behind in the wedding ritual of the Church of Sweden. ${ }^{5}$ But the modern belief in fate is decidedly not a 'survival' of ancient religion but the spontaneous creation of a secularized culture.

1 Baetke, Art und Glaube, p. 74 .

2 Esaias Tegnér, Samlade skrifter. Nationalupplaga, vol. I, Stockholm I923, pp. I $52 \mathrm{f}$.

${ }_{3}$ Gehl, op. cit., p. $4^{6}$

“ See Âke V. Ström, “Germanerna”, in: Ringgren-Ström, Religionerna, pp. 377 f.

5 Helge Ljungberg, "Vårdtecken». En liturgisk-etymologisk undersökning till I 529 års handbok, Kyrkohistorisk airsskrift 36, I936, pp. 28I-298.

Proof Addition to pp. $66 \mathrm{f}$. More literature from the I930's: W. Mohr, Schicksalsglauben und Heldentum (= Die Welt der Germanen 3), Leipzig 1935, H. Buttgereit, „Die Schichsalsauffassung der Germanen", Zeitschrift für deutsche Bildung 15 , 1939, pp. I97 ff., W. Wirth, Der Schicksalsglaube in den Isländersagas (=Veröffentlichungen des Orientalischen Seminars der Universität Tübingen II, Veröffentlichungen des Arischen Seminars r), Stuttgart r940. - Literature after I955: J. de Vries, "Gott, Mensch und Schicksal bei den Germanen”, Der nete Bund 7, r958, M. C. van den Toorn, „Über die Ethik in den Fornaldarsagas", Acta Philologica Scandinavica 26, 1964, pp. I9-66 (fate in pp. 55-57). F. P. Pickering, "Notes on fate and fortune", Mediæval German studies. Presented to Frederick Norman, London i 965 , pp. I-1 5. 